\title{
Influence of Etching Time and Bonding Strategies on the Microshear Bond Strength of Self- and Light-Cured Pit-and-Fissure Sealants
}

\author{
Eduardo José SOUZA-JUNIOR ${ }^{1}$ \\ Boniek Castillo Dutra BORGES ${ }^{2}$ \\ Marcos Antônio Japiassú Resende MONTES ${ }^{3}$ \\ Roberta Caroline Bruschi ALONSO ${ }^{4}$ \\ Glaucia Maria Bovi AMBROSANO ${ }^{5}$ \\ Mário Alexandre Coelho SINHORETI ${ }^{1}$ \\ ${ }^{1}$ Departament of Restorative Dentistry, Piracicaba Dental School, \\ UNICAMP - University of Campinas, Piracicaba, SP, Brazil \\ ${ }^{2}$ Departament of Dentistry, Dental School, Potiguar University (Laureate International Universities), Natal, RN, Brazil \\ ${ }^{3}$ Departament of Restorative Dentistry, Dental School, UPE - University of Pernambuco, Camaragibe, PE, Brazil \\ ${ }^{4}$ UNIBAN - Bandeirante University of São Paulo, São Paulo, SP, Brazil \\ ${ }^{5}$ Departament of Community Dentistry, Piracicaba Dental School, \\ UNICAMP - University of Campinas, Piracicaba, SP, Brazil
}

\begin{abstract}
This study evaluated the impact of extended etching and bonding strategies on the microshear bond strength of three sealant materials. Two pit-and-fissure sealants [FluroShield, Dentsply (light-cured) and AlphaSeal, DFL (self-cured)] and one light-cured flowable composite resin (Permaflo, Ultradent) were evaluated according to different enamel etching times ( $15 \mathrm{~s}$ or $30 \mathrm{~s})$ and bonding procedures (no adhesive application, application of primer/hydrophobic resin or hydrophobic resin only). Intact enamel blocks were obtained from bovine teeth and sealed via the tested protocols. After $24 \mathrm{~h}$, the microshear bond strength test was performed in a universal testing machine at a crosshead speed of $0.5 \mathrm{~mm} / \mathrm{min}$. Failure modes were classified by stereomicroscopy. Data were submitted to a three-way ANOVA and to Tukey's test $(\alpha=0.05)$. There was no statistically significant difference $(p>0.05)$ among the materials. Permaflo showed higher bond strength when etched for $30 \mathrm{~s}$ alone. Enamel overetching decreased the bond strength of the light-cured sealant. Primer/ bond previous treatment improved bond performance for AlphaSeal. In conclusion, from the tested conditions, all sealant materials presented similar bond strength values in relation to bonding protocol and etching time. The flowable composite can be used as a pitand-fissure sealant. The use of a three-step adhesive system was essential for the self-cured sealant application.
\end{abstract}

Key Words: pit-and-fissure sealants, enamel, shear bond strength.

\section{INTRODUCTION}

With the advent of modern dentistry, preservation of the dental structure and avoidance of surgical treatment have become treatment goals $(1,2)$. In this sense, pit-and-fissure sealants have been recognized as an effective method for preventing caries initiation and arresting caries progression by providing a physical barrier that inhibits microorganisms and food particles from collecting in pits and fissures (3).

However, it is generally accepted that the efficacy of sealants in caries prevention depends on sealant long-term retention (4). It has been reported that the loss of sealant is directly related to subsequent caries development (5). Moreover, Borges et al. (6) showed that a pit-and-fissure sealant was able to arrest the progression of non-cavitated occlusal lesions in dentin, since the sealant remains intact on the pits and fissures. Therefore, there is a need for an adhesive protocol that provides a higher retention of the sealing material than the conventional method, since it would increase the primary and secondary preventive benefits of sealants.

Correspondence: Prof. Dr. Eduardo José Souza-Junior, Departamento de Odontologia Restauradora, Faculdade de Odontologia de Piracicaba, UNICAMP, Caixa Postal 52, Avenida Limeira, 901, Areião,13414-903 Piracicaba, SP, Brasil. Tel. +55-19-8841-5291. e-mail: edujcsj@gmail.com 
Adhesive materials may be used as an intermediary layer between the etched enamel and resin sealant in order to improve adhesion of pit-and-fissure sealants (7), and three-step etch-and-rinse adhesives remain the gold standard in terms of bond durability (8). However, the previous optimal acid etching time for pit-and-fissure sealants remains questionable since the most recent works used composite resin (9) and ground enamel (10).

The use of dentin primer on enamel is also a controversial approach in the placement of a pit-andfissure sealant, due to the different results presented in the literature $(11,12)$, which tested composite resin on flattened enamel. Because fissure walls consist of intact, aprismatic enamel instead of ground prismatic enamel (13), it is important to clarify the benefits of longer acid etching time and bonding strategies for unground enamel when using pit-and-fissure sealant materials. Additionally, conventional self-cured and light-cured sealants, resin-based materials, such as flowable composite resins, can provide an alternative approach for sealing pits and fissures (14). Composites based on Bis-GMA monomers are traditionally used as sealant materials combined with phosphoric acid etching. These materials have lower inorganic filler content, which accounts for the low-viscosity behavior, thereby increasing the penetration of the composite into the pits and fissures (15) and producing a sealing effect.

Although it has been stated that flowable composites are suitable materials for sealant procedures - due to their low viscosity, high wettability (16) and satisfactory clinical performance (17) - the literature does not clarify the interactions of these materials with the enamel substrate etched during different times and bonded by distinct adhesive strategies. Thus, the aim of this study was to verify the effects of phosphoric acid etching time and bonding protocol on the microshear bond strength of three materials used as pit-andfissure sealants. The first assumed hypothesis was that increasing phosphoric acid etching time could provide higher microshear bond strength values for intact enamel. The second hypothesis proposed that bonding protocols could increase sealant bond strength.

\section{MATERIAL AND METHODS}

Twenty-one bovine incisors were selected, cleaned and stored in a $0.5 \%$ chloramine $\mathrm{T}$ solution at $4^{\circ} \mathrm{C}$ for no more than one week. Roots were sectioned off $1 \mathrm{~mm}$ under the cementoenamel junction, using a double-faced diamond saw (K.G. Sorensen, São Paulo, SP, Brazil). Next, the crown was sectioned into six enamel fragments $(4 \mathrm{~mm} \times 4 \mathrm{~mm})$, using a slow-speed diamond saw (Isomet 1000; Buehler Ltd., Lake Bluff, IL, USA) under water cooling. Each fragment was embedded in polystyrene resin to facilitate handling, keeping the buccal surface exposed. The surfaces were kept intact in a flat disposition, maintaining a sufficient area to build up the tested sealant materials ( $1 \mathrm{~mm}$ diameter).

The specimens $(n=42)$ were rinsed with water and the debris were ultrasonically cleansed for $20 \mathrm{~min}$. Enamel fragments were allocated to one of the following treatments: Group 1: 37\% phosphoric acid (Condac 37, FGM, Joinville, SC, Brazil), for 15 s only; Group 2: $37 \%$ phosphoric acid for $15 \mathrm{~s}$, followed by primer and hydrophobic resin application (Scotchbond MultiPurpose; 3M ESPE, St Paul, MN, USA); Group 3: 37\% phosphoric acid, for $15 \mathrm{~s}$, followed by hydrophobic resin application (Scotchbond Multi-Purpose) only; Group 4: 37\% phosphoric acid for 30 s only; Group 5: $37 \%$ phosphoric acid for $30 \mathrm{~s}$, followed by primer and hydrophobic resin application; Group 6:37\% phosphoric acid for $30 \mathrm{~s}$, followed by hydrophobic resin application.

The hydrophobic resin was light-cured at a $3 \mathrm{~mm}$ distance, according to the manufacturer's instructions, using a LED unit (FlashLite 1401; Discus Dental, Culver City, CA USA) with $950 \mathrm{~mW} / \mathrm{cm}^{2}$ light intensity. The radiance was measured with a curing radiometer (model 100; Demetron Research Corporation, Danbury, CT, USA) and a $3 \mathrm{~mm}$ distance was established by a digital caliper coupled to a metallic holder.

Three sealing materials were applied $(n=7)$ : Alpha Seal self-cured pit-and-fissure sealant (DFL, Rio de Janeiro, RJ Brazil), FluoroShield light-cured pit-and-fissure sealant (Dentsply Ind. e Com. Ltda., Petrópolis, RJ, Brazil) and Permaflo light-cured flowable composite resin (Ultradent, South Jordan, UT, USA). The materials' compositions and batch numbers as well as the irradiance of the light-curing unit used in the study are shown in Table 1.

A cylindrical translucent Tygon mold (Tygon tubong, TYG-030; Saint-Gobain Performance Plastics, Maime Lakers, FL, USA), with a $1 \mathrm{~mm}$ internal diameter and $1 \mathrm{~mm}$ high, was positioned over the bonded specimen and the sealant material was inserted into the mold. Next, the light-cured materials were photoactivated for 20 $\mathrm{s}$, in accordance with the manufacturer's instructions, with the curing-light tip set to $3 \mathrm{~mm}$ far from material surfaces $(14,18)$. The self-cured Alpha Seal sealant was 
left undisturbed for $24 \mathrm{~h}$.

\section{Microshear Bond Strength}

After $24 \mathrm{~h}$, the embedded specimens were attached to the testing device and each sealant cylinder was tested on a universal testing machine (EMIC DL 2000, São José dos Pinhais, PR, Brazil). A thin steel wire $(0.2 \mathrm{~mm}$ diameter $)$ was looped around each cylinder, and a shear load was applied to the base of each cylinder, at a crosshead speed of $0.5 \mathrm{~mm} / \mathrm{min}$, until failure. Microshear bond strength was calculated and expressed in MPa. Data were submitted to three-way ANOVA (sealant material $\mathrm{x}$ etching time $\mathrm{x}$ bonding protocol) with subparcels (acid etching time and adhesive procedures) and Tukey's test at a pre-set alpha of 0.05. The fractured specimens were observed on a stereomicroscope (Zeiss, Manaus, $\mathrm{AM}$, Brazil) at $\times 25$ magnification to evaluate the fracture patterns. The failure modes were classified into four types: Type 1: adhesive failure between bonding agent and enamel; Type 2: cohesive failure within enamel or in the sealant material; Type 3: cohesive failure within the adhesive; and Type 4: mixed failure.

\section{RESULTS}

\section{Microshear Bond Strength}

For the microshear bond strength, there was no statistically significant difference $(p>0.05)$ between the sealing materials However, there were statistically significant differences $(p<0.05)$ between etching times, among adhesive application procedures and in the interaction among sealer materials $\mathrm{x}$ etching times $\mathrm{x}$ adhesive procedures. The bond strength mean values (in MPa) for the tested conditions and materials and results of Tukey's test are shown in Table 2. Longer etching time increased the bond strength of Alphaseal only when no adhesive was applied before its placement on the enamel. When the enamel was etched for $15 \mathrm{~s}$, the application of primer and hydrophobic resin provided the highest bond strength of Alphaseal. When the enamel was acid etched for $30 \mathrm{~s}$, no benefits were found for any bonding agent. FluoroShield showed a higher bond strength when the enamel was etched for $15 \mathrm{~s}$, regardless of the bonding protocol. The

Table 2. Mean bond strength values ( $\mathrm{MPa})$ and standard deviations for the tested conditions and materials.

\begin{tabular}{lccc}
\hline Sealing material & $\begin{array}{c}\text { No bond } \\
\text { treatment }\end{array}$ & Primer/SBMP & SBMP \\
\hline Alphaseal 15 s & $12.5(2.9) \mathrm{Cb}$ & $30.7(8.0) \mathrm{Aa}$ & $22.5(9.5) \mathrm{Ba}$ \\
Alphaseal 30 s & $17.7(5.5) \mathrm{Aa}$ & $18.6(6.0) \mathrm{Ab}$ & $16.3(6.0) \mathrm{Aa}$ \\
Fluoroshield 15 s & $22.9(3.0) \mathrm{Aa}$ & $18.7(3.7) \mathrm{Aa}$ & $23.6(3.7) \mathrm{Aa}$ \\
Fluoroshield 30 s & $12.5(2.6) \mathrm{Ab}$ & $14.3(4.5) \mathrm{Ab}$ & $16.8(2.9) \mathrm{Ab}$ \\
Permaflo 15 s & $12.6(3.7) \mathrm{Bb}$ & $22.81(4.3) \mathrm{Aa}$ & $23.4(5.0) \mathrm{Aa}$ \\
Permaflo 30 s & $23.7(8.3) \mathrm{Aa}$ & $21.1(6.3) \mathrm{Aa}$ & $22.6(6.7) \mathrm{Aa}$ \\
\hline
\end{tabular}

SBMP: Scotchbond Multi-Purpose (hydrophobic resin). Mean values followed by different lowercase letters in columns and uppercase letters in rows, for each material, differ statistically among themselves (Tukey's test at $\mathrm{p}<0.05$ ).

Table 1. Information about the sealants used in the study.

\begin{tabular}{|c|c|c|c|c|}
\hline Material & Brand name (manufacturer) & Shade & Batch & Composition \\
\hline $\begin{array}{l}\text { Pit-and- } \\
\text { fissure } \\
\text { sealant }\end{array}$ & $\begin{array}{l}\text { AlphaSeal (DFL, } \\
\text { Rio de Janeiro, RJ, Brazil) }\end{array}$ & No & $135 \mathrm{~B}$ & $\begin{array}{l}\text { Alphaseal auto A: BisGMA', TEGDMA }{ }^{\mathrm{B}}, 2,6 \\
\text { DI, } 2 \text { hydroxy-propilaniline (NN BIS'), UV Stab, } \\
\text { methacrylic acid, aminoesters, amine. } \\
\text { Alphaseal auto K: BisGMA', TEGDMA, 2,6 DI, } \\
\text { benzoil peroxide. }\end{array}$ \\
\hline $\begin{array}{l}\text { Pit-and- } \\
\text { fissure } \\
\text { sealant }\end{array}$ & $\begin{array}{l}\text { FluroShield (Dentsply Ind. e Com. } \\
\text { Ltda., Petrópolis, RJ, Brazil) }\end{array}$ & Opaque & $142812 B$ & $\begin{array}{c}\text { UED-BisGMA }{ }^{\mathrm{C}}(<40 \%) \text {; Resins }(<10 \%) \text {; PENTA } \\
(<5 \%) \text {; Bis-GMA }(<5 \%) \text {; glass filler }(<30 \%) \text {; } \\
\text { amorphous silica }(<2 \%) ; \mathrm{TiO}_{2}(<3 \%) ; \mathrm{NaF}(<5 \%)\end{array}$ \\
\hline $\begin{array}{l}\text { Flowable } \\
\text { composite }\end{array}$ & $\begin{array}{l}\text { Permaflo (Ultradent Products, South } \\
\text { Jordan, UT, USA) }\end{array}$ & A2 & 182017B & $\begin{array}{c}\text { Bis-GMA }^{\mathrm{A}}(8.5 \%) ; \text { TEGDMA }^{\mathrm{B}}(20 \%) \text {; sodium } \\
\text { monoflurophosphate }(0.3 \%) \text {; Zirconium filler }(68 \%)\end{array}$ \\
\hline
\end{tabular}

ABisphenol-A-glycidyl methacrylate; ${ }^{\mathrm{B} T}$ Triethylene glycol dimethacrylate; ${ }^{\mathrm{C}}$ Urethane modified Bis-GMA dimethacrylate. 
flowable composite Permaflo presented higher bond strength when the enamel was etched for $30 \mathrm{~s}$ and no adhesive agent was applied. The application of primer and/or hydrophobic resin increased the bond strength of Permaflo only when the enamel was etched for $15 \mathrm{~s}$.

\section{Failure Modes}

The failure modes of the tested samples for each sealing material are shown in Figures 1-3. For Alphaseal, there was a predominance of mixed and adhesive failures. Only for 30 s-etched enamel, this self-cured sealant presented cohesive failures in the sealant. FluoroShield showed a predominance of adhesive failures. The flowable composite presented mixed failures primarily when a bonding pre-treatment was used. In general, adhesive failure was the most frequent pattern found in all the tested experimental conditions.

\section{DISCUSSION}

The clinical success of pit-and-fissure sealant is well documented in the literature and is directly related to its capacity of bonding to occlusal pits and fissures (4). The hardened material forms a strong micromechanical bond to etched tooth enamel, thus physically obliterating susceptible areas of the tooth surface and preventing the onset of dental caries (3). Pit-and-fissure sealants

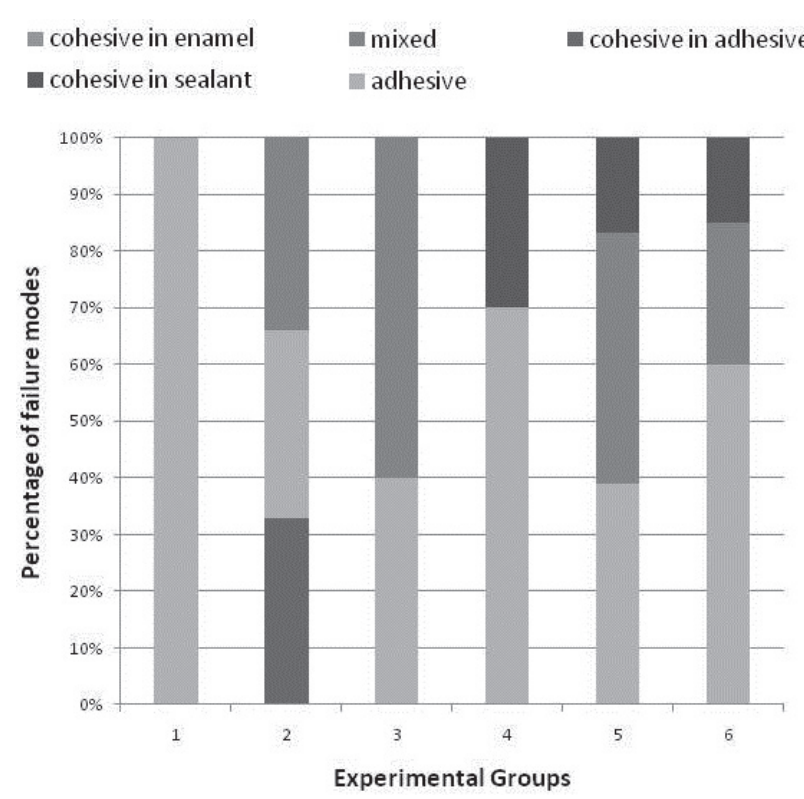

Figure 1. Failure modes (\%) for Alphaseal. require an enamel acid etching in order to allow material infiltration into porosities, which yields mechanical strength and clinical retention. Shear bond strength test has been used elsewhere to test sealant adhesion $(7,19)$.

Phosphoric acid at a $30-40 \%$ concentration is the most common strategy for increasing the surface free energy of enamel and dentin (8) before using adhesive restorative materials. A $15 \mathrm{~s}$ acid application causes a satisfactory enamel etching for either a three-step or two-step etch-and-rinse adhesive system subsequent to application (7). However, some authors have attempted to clarify whether a long etching time could provide benefits for the adhesion of restorative materials to dental tissues $(9,10)$. It has been observed that extended enamel acid etching does not affect the bond strength of adhesive systems (9). This conclusion is in accordance with some results obtained in the present study.

Only for Alphaseal and Permaflo sealants, extended acid etching (30 s) showed higher bond strength values when no previous bonding protocol was used, so the first tested hypothesis was partially validated. This may be explained by the fact that an extended acid etching time might increase enamel prisms' dissolution, in comparison with a $15 \mathrm{~s}$ etching time, thereby enhancing the effect of demineralization. In this way, longer phosphoric acid etching promoted some cohesive failures in the sealant, compared with the conventional etching time of $15 \mathrm{~s}$, which only yielded

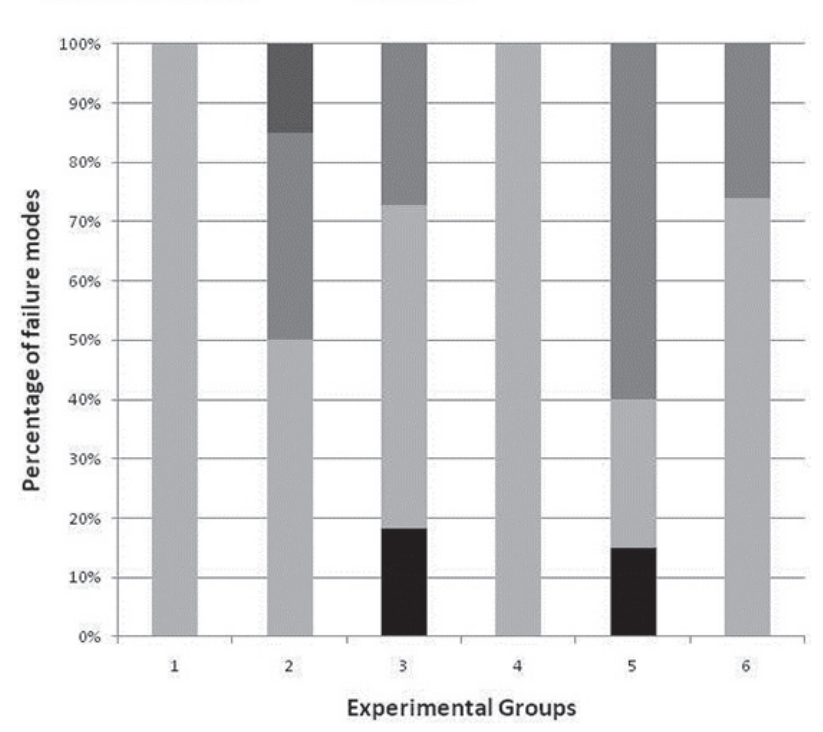

Figure 2. Failure modes (\%) for Permaflo. 
adhesive failures for the sealants. Although bond strength values were significantly higher when these sealants were used with $15 \mathrm{~s}$ enamel etching, mixed failures were more frequent when the bonding agent was applied with the longer etching time (30 s).

For the flowable composite and the self-cured sealant, higher demineralization and increased surface free energy, after $30 \mathrm{~s}$ etching time, probably produced a higher material infiltration into the enamel prisms. Hence, higher bond strength means were found for these materials when no bonding agent was applied previously. Permaflo showed bond strength results similar to the application of a bonding agent. Accordingly, the applied bond agent, regarding the presence of a primer compound, did not affect bond strength, as reported elsewhere $(11,12)$. Doubling enamel etching to $30 \mathrm{~s}$ did not improve the failure mode of the tested specimens for Permaflo.

On the other hand, a $30 \mathrm{~s}$ acid etching time decreased the bonding performance of FluoroShield, regardless of the bonding strategy. FluroShield's manufacturer recommends a $15 \mathrm{~s}$ phosphoric acid application in order to obtain adequate bond performance. Over-etching the intact enamel may cause a poor sealant infiltration, especially when photocured immediately after application. Hydrophobic monomers, such as UED-BisGMA, PENTA-Phosphate, and BisGMA, present higher length chains with higher viscosity,

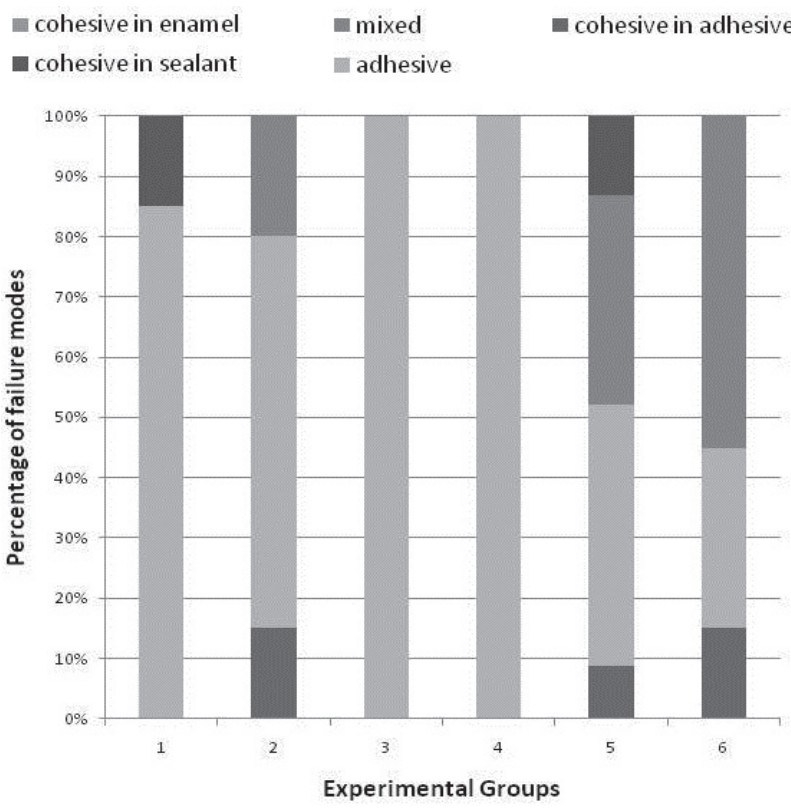

Figure 3. Failure modes (\%) for FluoroShield. making it difficult for them to penetrate into the enamel interprismatic demineralized spaces. Nevertheless, Alphaseal was better retained when an longer etching time was performed with no subsequent bonding treatment, perhaps because its self-curing mode may facilitate a better material flow until the completion of the polymerization reaction of benzoil peroxide and amine system. Thus, from a clinical standpoint, FluoroShield should be applied on a 15 s-etched enamel.

It is common sense that enamel over-etching with $35-37 \%$ phosphoric acid does not alter bond strength. On the other hand, the literature also shows an increase in immediate bond performance when enamel etching is extended (10). In this study, over-etching benefits were material-dependent; hence, the monomer composition and percentage of inorganic filler possibly influenced the results.

The enamel used in this work was intact, presenting different characteristics from those of ground enamel (20). The intact pit-and-fissure enamel presents an aprismatic layer that is less susceptible to micromechanical retention, since the absence of prisms does not allow a proper surface for resin tag formation (20). When submitted to acid etching, only slender and irregular microporosities are formed, with no preferential etching of prism cores or peripheries, like ground enamel with prismatic distribution (4). Therefore, etching prismless enamel can increase both surface area and energy, yielding a satisfactory monomer infiltration into the microporosities. Although natural bovine enamel presents higher roughness than ground enamel or human enamel, bovine dental substrate roughness has no correlation with orthodontic bracket shear bond strength (21); hence, unground enamel could have not influenced the results of this work. Moreover, unground bovine enamel has been used elsewhere to evaluate sealant bond strength (13), though it has been considered a valid substitute for research on human teeth (21).

In the present study, the bonding performance of the tested sealants on intact enamel showed that a longer etching time either increases or does not affect bond strength, depending on the used adhesive bonding procedures, except for FluoroShield. The literature indicates that the previous application of an intermediary layer of bonding system onto the etched enamel, before sealant placement, can improve sealant adhesion even to oil-contaminated enamel (7). As in the present study the bonding protocols did not improve bond strength for Fluroshield, the second hypothesis was partially 
validated. For Alphaseal, using the primer component of the three-step etch-and-rinse Scotchbond Multi-Purpose was important for providing higher bond strength values, compared with previous application of the hydrophobic resin only, when enamel was etched for $15 \mathrm{~s}$. In this case, the interaction between the sealant and enamel might have been improved.

In the present investigation, the microshear bond strength of Permaflo was not influenced by the bonding strategy when the enamel was acid etched for $30 \mathrm{~s}$. It may be assumed that a demineralization pattern caused by $30 \mathrm{~s}$ acid etching was sufficient to provide excellent contact of the material with the interprismatic spaces, so that the application of bonding agents did not offer any benefits for the bond strength of Permaflo. On the other hand, a $15 \mathrm{~s}$ acid etching probably could not demineralize the enamel more deeply, which would stimulate the application of bonding agents in order to improve the interaction between Permaflo and enamel.

Applying a hydrophilic primer before the hydrophobic resin might not affect retention for a lightcured sealant, since the thin layer of the sealing material may allow light penetration to achieve the adhesive monomers and to induce higher monomer conversion. Although the microshear bond strength test has been used in a number of studies $(9,22)$, it has some limitations. One disadvantage of this test is the fluid capillarity of the adhesive, caused by placing the Tygon tube on the tooth substrate before bonding application prior to photocuring. In an attempt to avoid this problem, some studies have proposed light curing the bonding adhesive before placing the Tygon mold $(12,22)$. Even if it avoids fluid capillarity, this method results in an excess of the adhesive layer under the composite material. In this way, it can affect bond strength values and hence needs to be clarified. Also, this study did not use any aging protocol for adhesive interfaces after sealant placement. Additionally, adhesive interface analysis was not performed; accordingly, further studies should analyze sealant and adhesive interface characteristics after aging simulation protocols, in an attempt to confirm the main findings of this investigation.

Flowable composites used as pit-and-fissure sealants may provide a promissory substitute for conventional light-activated or self-curing fissure sealants. Some authors have found superior retention levels in comparison with conventional sealants (17) and it has been shown that a low-viscosity composite presents higher physical properties than the traditional fissure sealant Fluroshield $(14,18)$, thereby yielding higher mechanical strength and degradation resistance in the oral environment.

To evaluate dental materials, carefully conducted, randomized, controlled clinical trials are considered as standard. However, considerable time and resources are needed to conduct these trials. Further, dental materials evolve rapidly. Therefore, the clinical success of these materials must be estimated in an easy, rapid and realistic way. Bond strength evaluation of pit-and-fissure sealants after polymerization may predict their long-term clinical success, and novel adhesive approaches must be investigated and/or clarified before clinical trials.

In conclusion, all tested sealing materials presented similar bond strength values, regardless of the bonding protocol and the etching time. The flowable composite resin can be used as a pit-and-fissure sealant, however achieving adequate bond strength values only when etched for $30 \mathrm{~s}$. The light-cured and self-cured sealants should be etched for $15 \mathrm{~s}$ in order to achieve adequate enamel retention. The use of a three-step adhesive system is essential before placement of the self-cured sealant.

\section{RESUMO}

Este trabalho avaliou o impacto de tempos aumentados de condicionamento ácido e da estratégia adesiva na resistência de união por microcisalhamento de três materiais utilizados como selantes de fóssulas e fissuras. Dois tradicionais selantes, [FluroShield, Dentsply (fotoativado) e AlphaSeal, DFL (quimicamente ativado)] e uma resina composta de baixa viscosidade (Permaflo, Ultradent) foram utilizados de acordo com diferentes tempos de condicionamento ácido ( $15 \mathrm{~s}$ e $30 \mathrm{~s}) \mathrm{e}$ diferentes estratégias de união (sem aplicação de sistema adesivo, aplicação de um primer + resina hidrófoba, e aplicação apenas de uma resina hidrófoba). Fragmentos de esmalte intacto foram obtidos de incisivos bovinos e os materiais foram aplicados respeitando-se os protocolos anteriormente descritos. Após 24 $\mathrm{h}$, o teste de microcisalhamento foi executado utilizando-se uma máquina de ensaio universal, com velocidade de $0,5 \mathrm{~mm} /$ min. O padrão de fratura foi classificado com auxílio de lupa estereoscópica. Os dados foram submetidos aos testes ANOVA a três critérios e de Tukey $(\alpha=0.05)$. Não houve diferenças estatisticamente significantes entre os materiais. Permaflo apresentou maior resistência de união quando o esmalte foi condicionado por $30 \mathrm{~s}$ apenas. O sobrecondicionamento do esmalte diminuiu a resistência de união do selante fotopolimerizável. O tratamento prévio do esmalte com primer + resina hidrófoba melhorou a performance adesiva para o AlphaSeal. Todos os materiais apresentaram valores de resistência de união estatisticamente similares em relação ao protocolo adesivo e ao tempo de condicionamento ácido. A resina composta de baixa viscosidade poderá ser utilizada como selante de fóssulas e fissuras. A aplicação de um sistema adesivo de três passos é 
essencial durante o selamento com selante quimicamente ativado.

\section{REFERENCES}

1. Martignon S, Ekstrand KR, Gomez J, Lara JS, Cortes A Infiltrating/sealing proximal caries lesions: A 3-year randomized clinical trial. J Dent Res 2012;91:288-292.

2. McComb D. Conservative operative management strategies. Dent Clin N Am 2005;49:847-865.

3. Kantovitz KR, Pascon FM, Correr GM, Alonso RC, Rodrigues LK, Alves MC, Puppin-Rontani RM. Influence of environmental conditions on properties of ionomeric and resin sealant materials. J Appl Oral Sci 2009;17:294-300.

4. Papacchini F, Cury AH, Goracci C, Chieffi N, Tay FR, Polimeni A, et al. Noninvasive pit and fissure sealing: microtensile bond strength to intact bovine enamel of different pit and fissure sealants in a simplified fissure model. J Adhes Dent 2006;8:375-380.

5. Tianviwat S, Chongsuvivatwong V, Sirisakulveroj B. Loss of sealant retention and subsequent caries development. Community Dent Health 2008;25:216-220.

6. Borges BC, Campos GB, Silveira AD, Lima KC, Pinheiro IV. Efficacy of a pit and fissure sealant on arresting dentin noncavitated caries: a 1-year follow-up, randomized, controlled clinical trial. Am J Dent 2010;23:311-316.

7. Borsatto MC, Thomaz MY, Contente MM, Gomes-Silva JM, Mellara TS, Galo R, et al.. Bonding agent underneath sealant: shear bond strength to oil-contaminated enamel. Braz Dent $\mathrm{J}$ 2010;21:50-54.

8. De Munck J, Van Landuyt K, Peumans M, Poitevin A, Lambrechts $\mathrm{P}$, Braem M, et al.. A critical review of the durability of adhesion to tooth tissue: methods and results. Dent Res 2005;84:118-132.

9. Pivetta MR, Moura SK, Barroso LP, Lascala AC, Reis A, Loguercio $\mathrm{AD}$, et al.. Bond strength and etching pattern of adhesive systems to enamel: effects of conditioning time and enamel preparation. J Esthet Restor Dent 2008;20:322-335.

10 Barkmeter WW, Erickson RL, Kimmes NS, Latta MA, Wilwerding TM. Effect of enamel etching time on roughness and bond strength. Oper Dent 2009;34:217-222.

11 Jain P, Stewart GP. Effect of dentin primer on shear bond strength of composite resin to moist and dry enamel. Oper Dent $2000 ; 25: 51-58$
12 Woronko GA Jr, St Germain HA Jr, Meiers JC. Effect of dentin primer on the shear bond strength between composite resin and enamel. Oper Dent 1996;21:116-121.

13 Papacchini F, Goracci C, Sadek FT, Monticelli F, Garcia-Godoy F, Ferrari M. Microtensile bond strength to ground enamel by glassionomers, resin-modified glass-ionomers, and resin composites used as pit and fissure sealants. J Dent 2005;33:459-467.

14 Borges BC, Bezerra GV, Mesquita JA, Pereira MR, Aguiar FH, Santos AJ, et al. Effect of irradiation times on the polymerization depth of contemporary fissure sealants with different opacities. Braz Oral Res 2011;25:135-142.

15 Marcushamer M, Neuman E, García-Godoy F. Fluoridated and nonfluoridated unfilled sealants show similar shear strength Pediat Dent 1997;19:289-290

16 Attar N, Tam LE, McComb D. Flow, strength, stiffness and radiopacity of flowable resin composites. J Can Dent Assoc 2003;69:516-521.

17. Corona SA, Borsatto MC, Garcia L, Ramos RP, Palma-Dibb RG. Randomized, controlled trial comparing the retention of a flowable restorative system with a conventional resin sealant: one-year follow up. Int J Paediatr Dent 2005;15:44-50.

18 Borges BC, Silva PR, Catelan A, Aguiar FH. Influence of the light curing tip distance and material opacity on selected physical properties of a pit and fissure sealant. Pediatr Dent 2011;33:505509.

19 Gomes-Silva JM, Torres CP, Contente MM, Oliveira MA, PalmaDibb RG, Borsatto MC. Bond strength of a pit-and-fissure sealant associated to etch-and-rinse and self-etching adhesive systems to saliva-contaminated enamel: individual vs. simultaneous light curing. Braz Dent J 2008;19:341-347.

20 Perdigão J, Fundingsland JW, Duarte Jr S, Lopes MM. Microtensile adhesion of sealants to intact enamel. Int J Paediatr Dent 2005;15:342-348.

21 Sabatoski MA, Maruo IT, Camargo ES, Guariza-Filho O, Tanaka $\mathrm{OM}$, Maruo $\mathrm{H}$. Influence of natural bovine enamel roughness on bond strength after etching. Angle Orthod 2010;80:562-569.

22 Shimada Y, Tagami J. Effects of regional enamel and prism orientation on resin bonding. Oper Dent 2003;28:20-27.

Received September 2, 2011 Accepted April 13, 2012 